\title{
Comment
}

\section{United States - Sunset Reviews of Anti-Dumping Measures on Oil Country Tubular Goods from Argentina}

\section{Prepared for the ALI Project on the Case Law of the WTO}

\author{
ED WIN VERMULST \\ Vermulst Verhaeghe \& Graafsma, Brussels, Belgium. Email: edwin.vermulst@vvg-law.com
}

\section{Introduction}

Gene Grossman and Jasper Wauters have provided an excellent analysis of and commentary on the AB report United States - Sunset Reviews of Anti-Dumping Measures on Oil Country Tubular Goods [OCTG] from Argentina with much of which I agree. As a result, my observations below are of necessity short.

\section{The US: a victim of its transparency?}

It seems hard to deny that of all active user countries of antidumping measures, the United States is the most transparent. US antidumping law tends to provide more detail than is required under the WTO Anti-Dumping Agreement [ADA]. In addition, the US agencies have published detailed guidelines on how they will apply the law. Third, US administrative determinations tend to explain in great detail how findings were reached and why arguments made by interested parties were accepted or rejected. Last, the system of disclosure of confidential information under an administrative protective order offers legal counsel of interested parties the opportunity to vet the findings of the agencies in detail.

The US system contrasts in this respect with the system of many other countries, whose antidumping legislation tends to be a carbon copy of the provisions of the ADA. Administrative guidelines, if they exist, tend to be internal documents that are not disclosed to the public or interested parties. Administrative determinations are relatively short and often full of conclusory statements that copy language from the ADA (e.g.: 'It was found that a pattern of export prices existed which differed significantly among different purchasers, regions or time periods, and 
that such differences could not be taken into account appropriately by the use of a weighted average-to-weighted average or transaction-to-transaction comparison.'). Nonconfidential summaries of confidential information and disclosures of findings and calculations by the agencies, notably on injury and the calculation of injury margins, tend to be so vague that they often leave interested parties, let alone the public (which does not have access to nonconfidential summaries and disclosures), guessing at how exactly the agencies arrived at their conclusions. ${ }^{1}$

This may - at least partially - explain why so many of the WTO cases in the antidumping area have targeted the United States. ${ }^{2}$ It is easier to claim violations of ADA provisions when it is clear what the investigating authorities have done than if one first has to decipher what the authorities have done and on what basis and, even more importantly, obtain the evidence to prove it before a WTO panel.

Section II.A.3 of the SPB illustrates this point: It contains three scenarios that will 'normally' lead the DOC to determine that revocation of an antidumping order is likely to lead to continuation or recurrence of dumping. Within the weird world of antidumping, these scenarios make sense and probably are applied as a matter of practice by many other investigating authorities in sunset reviews, as long as the complainants are pushing for continuation of the duties. But they will not be written down, thereby precluding 'as such' claims.

Viewed in this broader context, it is perhaps understandable that the $A B$ imposes a high evidentiary standard for 'as such' claims. Adoption of a low standard would punish countries such as the United States even more for their transparency and indirectly - and perversely - reward countries for maintaining nontransparent systems.

\section{Applicability of Article 3 in sunset reviews}

I agree with Grossman and Wauters that the injury disciplines of Article 3 ADA in general ought to apply equally to the determination of likely continuation or recurrence of injury in sunset (and interim) reviews, unless such application clearly does not make sense (see point 3 below).

If the focus in a sunset review is on the continuation of injury, this would appear to require a finding that injury, as defined in Article 3, is still occurring and that it would continue (or worsen) if the duties were to be lifted.

If the focus in a sunset review is on the recurrence of injury, there is no injury at present (possibly because the duties are 'working' or for other reasons), but there might be injury again if the duties were to be lifted. There is, in other words, a potential threat of injury. In such a case, the counterfactual analysis indeed should

1 In some jurisdictions, even the names of complainants are sometimes not disclosed because of confidentiality reasons!

2 Admittedly, the US is an aggressive enforcer of its antidumping legislation, but it is hardly the only one. 
be similar to the threat analysis required by Article 3.7 ADA, which per the Panel in Mexico-Corn Syrup necessitates consideration of the Article 3.4 factors.

\section{Applicability of cumulation and its conditions in sunset reviews}

There appears to be no reason, legal or conceptual, why the cumulation concept of Article 3.3 ADA would not apply in sunset reviews.

As regards the disciplines imposed on cumulation by that Article, I believe that a distinction must be made between the first two conditions (under (a)) and the last condition (under (b)).

I would argue that the last condition that a cumulative assessment of the effects of the imports must be appropriate in light of the conditions of competition between the imported products and the conditions of competition between the imported products and the domestic like product applies equally in sunset reviews. If, for example, there has been a change in consumer preferences as a result of which the imports from country A no longer compete with other imports or with the domestic like product, ${ }^{3}$ it would seem to me that imports from country A then would need to be decumulated.

On the other hand, the distinction between an original investigation and a sunset review would appear to justify nonapplicability of the de minimis dumping and negligible import volumes concepts in sunset reviews.

Indeed, the fact that duties were imposed in the original investigation entails that the imports during the original investigation period were dumped at more than de minimis levels and in nonnegligible quantities. A consequence of the imposition of the measures may well be that the dumping has dropped to a de minimis level or that the import volumes have become negligible. However, such developments do not guarantee that injurious dumping will not recur if the duties were to be lifted. Therefore, it would seem to me that such developments, in and of themselves, do not necessitate decumulation (in other words, automatic termination of the measures for the country concerned) in sunset reviews.

\section{The economics of dumping and of sunset reviews}

Grossman and Wauters start their analysis by pointing out that ' $[\mathrm{e}]$ conomic analysis of the sunset-review provisions of the AD Agreement is complicated by the fact that the agreement as a whole lacks a coherent economic justification and interpretation'. While many will agree with this observation, the fact of life is that WTO Members have agreed that antidumping duties may be imposed if the conditions are met. The determination of dumping under the ADA is a mathematical-calculation exercise in which the reasons why exporters dump are

3 This could be the case, for example, if consumption of the product under investigation has moved to higher-end models while one country continues to supply low-end models. 
irrelevant as a matter of law (indeed dumping may well be found because of the calculation methods authorized under the ADA) and not examined as a matter of practice. As long as this basic concept remains unchanged, any proposals to consider in sunset reviews what conditions led to dumping in the first place do not seem realistic.

Finally, I am not sure whether the imposition of antidumping duties has any deterrent effect in practice (and in fact may have the opposite effect in countries with prospective systems). It seems to me that firms' decisions on optimal pricing are based on an assessment of many elements, of which (the likelihood of) being subjected to antidumping duties is probably a relatively minor one. Perhaps a better analogy than the paroled thief who learns his lesson would then be the driver of a delivery van who regularly makes unauthorized stops to deliver his merchandise. The driver knows that he should not double-park or obstruct the sidewalk, but he really has no choice. Even if he is cited for a traffic violation, he will pay the fine and then do the same again the next day. 